\title{
Penatalaksanaan Kista Teratoid Leher
}

\author{
Nadya Dwi Karsa, Sukri Rahman
}

\begin{abstract}
Abstrak
Kista dermoid merupakan massa kistik subkutan yang terdiri dari epitel dan struktur adneksa. Secara histopatologi terdiri dari tiga jenis yaitu kista epidermoid, dermoid sejati dan teratoid. Kista teratoid merupakan variasi jarang dari kista dermoid. Kista teratoid timbul dari diferensiasi ektodermal sel multipotensial sepanjang proses fusi embrionik. Kista ini lebih sering terjadi pada laki-laki pada usia dekade kedua dan ketiga. Kista dapat terjadi di seluruh tubuh. Dilaporkan kasus seorang laki-laki usia 49 tahun dengan benjolan di leher yang membesar secara perlahan sejak 1 bulan dan hasil Computed Tomography (CT) Scan tiroid dan leher dicurigai sebagai kista tiroglosus dan didiagnosis banding dengan kista dermoid. Dilakukan penatalaksanaan dengan eksisi kista dalam anestesi umum dan dilakukan pemeriksaan patologi anatomi dengan hasil kista teratoid. Kista teratoid dapat berkembang di bagian tubuh manapun, namun sangat jarang pada kepala dan leher. Jika kista teratoid dapat terdiagnosis lebih awal dan ditatalaksana dengan eksisi kista secara komplit, maka prognosisnya lebih baik. Dari ketiga variasi kista dermoid, hanya kista teratoid yang dapat mengalami perubahan kearah keganasan.
\end{abstract}

Kata kunci: eksisi kista, histopatologi, kista teratoid

\begin{abstract}
Dermoid cysts are subcutaneous cystic mass consisting of epithelial and adnexal structures. Histopathologically dermoid cysts consist of 3 types of epidermoid cysts, true dermoid and teratoid. Teratoid cysts are a rare variation of dermoid cysts. Teratoid cysts arise from the multipotential differentiation of ectodermal cells throughout the embryonic fusion process. These cysts are often in men in the second and third decades of age. These cysts can occur throughout the body. It has been reported a case of a 49-year-old man with a lump in the neck that slowly enlarged during 1 month and the result of a CT scan of the neck suspected as a thyroglossal duct cyst with differential diagnoses a dermoid cyst. Management was a cyst excision under general anesthesia. The result of anatomical pathology examination was a teratoid cyst. The Teratoid cyst can develop anywhere in the body but rarely arise in the head and neck region. If teratoid cysts are diagnosed early and treated with complete surgical excision, the prognostic is good. Teratoid type is the only variety that may have a malignant change.
\end{abstract}

Keywords: cyst excision, histopathology, teratoid cyst

Affiliasi penulis: Bagian THT-KL, Fakultas Kedokteran, Universitas Andalas, Padang, Indonesia

Korespondensi: Sukri Rahman,

Email: sukrirahman@med.unand.ac.id Telp:+62 81266404069

\section{PENDAHULUAN}

Kista dermoid merupakan suatu massa kistik yang dilapisi oleh epitel gepeng disertai dengan adanya struktur adneksa seperti kelenjar sebasea, rambut, folikel rambut serta struktur lain seperti tulang, otot dan kartilago. Secara histopatologi kista dermoid terdiri dari 3 jenis yaitu kista epidermoid, dermoid sejati dan teratoid. Kista teratoid merupakan salah satu variasi yang jarang dari kista dermoid. Kista teratoid mengandung 3 macam lapisan embrionik yaitu ektoderm, mesoderm dan entoderm. Terdapat dua pendekatan operasi yaitu pendekatan intraoral dan ekstraoral (insisi leher) atau kombinasi keduanya, tergantung ukuran dan lokasi kista teratoid. 1,2

\section{Epidemiologi}

Kista dermoid mencakup 1,6-6,9\% dari semua kista pada kepala-leher. ${ }^{3,4}$ Kejadian kista teratoid hanya sekitar $1,8 \%$ dari semua jenis kista dermoid. ${ }^{4,5}$ 
Kista dermoid dapat terjadi di seluruh tubuh, sebanyak $7 \%$ terdapat di kepala-leher, dimana sekitar $23 \%$ nya berlokasi di dasar mulut (termasuk bibir, lidah dan mukosa bukal $)^{6}$. Lokasi lain yang dilaporkan adalah di mandibula, regio submental, usus besar, mediastinum, timus, nasofaring, spinal cord, ginjal dan mata. ${ }^{7}$

Kista ini umumnya lebih banyak pada laki-laki dibandingkan perempuan dengan ratio 3:1. ${ }^{1}$ Sangat jarang ditemukan pada usia bayi Kista ini muncul pada dekade dua sampai tiga kehidupan. ${ }^{1,2}$

\section{Etiologi}

Asal mula kista teratoid sama seperti perkembangan kista lainnya masih kontroversial. ${ }^{2}$ Ada dua teori yang telah dikemukakan, yaitu teori kongenital dan teori didapat. Teori kongenital mengemukakan bahwa kista ini berasal dari sel yang terperangkap saat penutupan garis tengah pada lengkung brankialis pertama dan kedua bilateral. $^{2}$

Kemungkinan teori asal kista kongenital lainnya meliputi diferensiasi ektoderm sel multipotensial terjepit pada saat penutupan neuropore anterior, kegagalan pemisahan permukaan ektoderm dari dasar neural tube, kemungkinan timbul dari tuberculum impar of His ${ }^{1}$ dan variasi dari kista duktus tiroglosus. ${ }^{2}$ Teori didapat mengemukakan bahwa kista berasal dari traumatik atau iatrogenik pada sel epitel atau sumbatan dari saluran kelenjar sebaseus. ${ }^{1,2}$

\section{Embriologi}

Faring menjadi bagian terbesar dari foregut selama beberapa minggu pertama pembentukan embriologi. ${ }^{8}$ Membran buccopharyngeal akan hilang pada akhir minggu ketiga dan digantikan oleh lapisan mesoderm membentuk struktur yang berbentuk huruf $\mathrm{U}$ pada bidang transversal yang menyatu secara ventral untuk membentuk 6 pasang lengkung faring atau lengkung brankialis ${ }^{8,9}$ (Gambar 1). Lengkungan kelima berukuran kecil dan cepat lenyap. ${ }^{8,10}$ Lengkungan dipisahkan secara eksternal oleh celah faring ektodermal dan secara internal oleh kantong faring endodermal. ${ }^{10}$ Setiap lengkungan berisi arteri, saraf, otot dan tulang rawan yang akan membentuk sebagian besar struktur leher. Lengkung brankialis

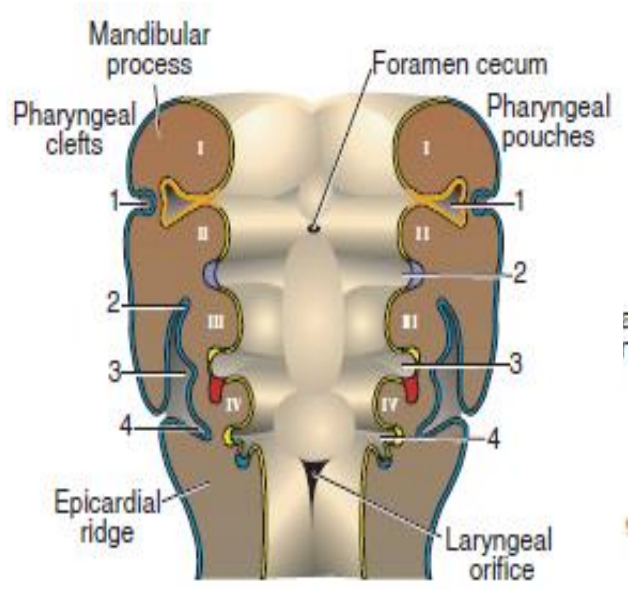

Gambar 1. Struktur embriologi lengkung brankialis ${ }^{y}$

pertama berisi tulang rawan dengan bagian dorsal yang dikenal sebagai prosesus maksila dan bagian ventral yang dikenal sebagai Meckel's cartilage atau prosesus mandibula. Kedua struktur ini akan beregresi dan membentuk Malleus dan Incus. ${ }^{8}$ Kantung faring pertama membentuk tuba eustachius, telinga tengah dan bagian tulang mastoid. ${ }^{11}$ Lengkung brankialis kedua dikenal sebagai Reichert's cartilage yang akan membentuk bagian atas tulang hyoid, prosesus styloid, ligamentum stylohyoid dan stapes. Lengkung brankialis ketiga akan membentuk bagian bawah tulang hyoid. ${ }^{11}$ Lengkung brankialis keempat dan keenam akan menyatu membentuk tulang rawan laring. Kantung faring keempat membentuk kelenjar paratiroid superior dan sel-sel parafolikular tiroid. ${ }^{8}$

\section{Gejala Klinis}

Kista dermoid pada kepala dan leher biasanya terjadi pada $T$ distribution yang melibatkan garis tengah wajah, anterior leher, orbita dan daerah periaurikular. ${ }^{12}$ Kista ini dapat ditemukan berdekatan dengan tulang hyoid dan ikut bergerak dengan gerakan menelan serta lidah dijulurkan, sehingga kista dermoid pada leher sering diragukan dengan kista duktus tiroglosus. ${ }^{11}$ Berdasarkan hubungannya dengan otot mylohyoid, kista dermoid berada di atas atau di bawah otot mylohyoid. ${ }^{6,13}$ Jika berada di atas otot mylohyoid, akan muncul sebagai benjolan di dalam mulut dan jika di bawah otot mylohyoid akan tampak sebagai benjolan di bagian tengah leher. ${ }^{13}$ 
Kista dermoid merupakan suatu massa kistik superfisial subkutan yang tidak nyeri, tidak terfiksir, pertumbuhannya lambat dan asimptomatik. ${ }^{1,10,11,14}$

Gejala klinis yang jarang terjadi adalah disfagia dan obstruksi jalan napas pada kista yang berukuran besar. Pertumbuhan yang cepat bisa terjadi secara sekunder akibat peningkatan mendadak deskuamasi atau selama kehamilan ${ }^{10}$ Pada palpasi kista teraba kenyal (a rubber-like sensation). ${ }^{6,15}$ Kista terkapsulasi dengan baik umumnya mengandung material keratin berwarna seperti keju kekuningan, kaseous, sebaceous, material purulen dengan butiran rambut, kuku dan lemak. ${ }^{2}$

\section{Gambaran Radiologi}

Diagnosis kista teratoid merupakan hal yang cukup sulit, selain anamnesis dan pemeriksaan fisik yang lengkap, juga diperlukan pemeriksaan penunjang yaitu pemeriksaan histopatologis dan radiologi seperti ultrasonografi (USG), CT Scan dan MRI. ${ }^{15,16}$ USG resolusi tinggi merupakan pemeriksaan pencitraan awal yang ideal untuk massa di leher yang bersifat kistik dan untuk mengetahui hubungan dengan struktur sekitarnya. ${ }^{17}$ Computed tomography (CT) lebih unggul dalam mengkonfirmasi temuan USG, menentukan luas lesi dan sangat bermanfaat dalam memberikan gambaran kalsifikasi atau lemak di dalam lesi. ${ }^{17}$ Magnetic resonance imaging (MRI) memiliki peran tambahan dalam menentukan lokasi lesi terutama untuk letak lesi yang lebih dalam dan luas. MRI sangat membantu membedakan kistik dari komponen padat. $^{17}$ Biopsi aspirasi jarum halus (BAJAH) mungkin diperlukan untuk konfirmasi diagnosis dalam beberapa kasus. ${ }^{17,18}$ Pada pemeriksaan USG tampak massa unilokular, berdinding tipis dan berbatas tegas, tampak gambaran gelembung-gelembung lemak dalam lumen yang membentuk "sac-of-marbles". Gelembung lemak di lumen muncul sebagai fokus echogenic yang memiliki bayangan akustik. Lapisan germinal pada kista dapat memberikan gambaran heterogenous. ${ }^{11,19}$ CT Scan memperlihatkan gambaran massa unilokular di garis tengah, berkapsul dan berbatas tegas, low density dan nonenhance. Pada pemeriksaan MRI didapatkan kista teratoid biasanya isointense atau hypointense terhadap otot pada atau hyperintense atau heterogeneous pada gambaran T2-weighted. ${ }^{10,11,15}$

Fistulografi dapat menunjukkan lokasi kista dan adanya saluran fistel serta hubungan ke tulang hyoid pada rontgent antero-posterior dan lateral. Fistulografi bersifat akurat, sederhana, cepat, invasif minimal dan sangat berguna untuk perencanaan bedah, tetapi jarang digunakan sebagai pemeriksaan rutin. ${ }^{25}$

\section{Histologi}

Menurut Meyer, kista dermoid terdiri dari 3 jenis yaitu kista epidermoid, dermoid sejati dan teratoid. ${ }^{1,2,7}$ Spouge membagi kista dermoid atas Simple, Compound, Complex. ${ }^{4,5} \quad$ Kista epidermoid (simple) dilapisi dengan epitel skuamosa sederhana, dengan dinding berserat dan tidak terdapat dermal appendages. Rongga kista tidak berisi sebum atau rambut. Kista ini berkembang dari bagian atas unit pilosebaseous. $^{2}$ Kista dermoid sejati (compound) dilapisi oleh epitel skuamosa bertingkat dan berkeratin dengan dermal appendages di dinding jaringan ikat. Lumen mengandung keratin, sebum dan berbagai variasi rambut dan lemak. $^{2}$ Kista teratoid (complex) dilapisi oleh berbagai jenis epitel mulai dari epitel skuamosa berkeratin sampai epitel kolumnar bertingkat semu dengan tambahan dermal di dinding jaringan ikat beserta derivat 3 lapisan embrionik (ektoderm, mesoderm dan entoderm). ${ }^{2}$

Lapisan embrionik dan derivatnya terdiri dari: ${ }^{20}$

\section{Ektoderm}

Kulit, epitel skuamosa, kelenjar sebasea dan

kelenjar keringat, rambut dan folikel rambut, gigi dan kuku, neuroectoderm, ependymal and choroid plexus, neuroglia and neurons

\section{Mesoderm}

Jaringan adipose,tulang, kartilago, otot

\section{Entoderm}

Lining epithelium (respiratorik, intestinal), kelenjar eksokrin (bronchial, gastric, intestinal), organ padat (pancreas, hepar, ginjal, paru, thyroid)

\section{Diagnosis Banding}

Diagnosis banding untuk kista teratoid di leher tergantung dari letak massa kista. Pada leher bagian lateral, kista celah brankialis adalah yang paling sering 
ditemukan. Kista ini terletak di sepanjang otot sternokleidomastoideus. Kista kongenital lainnya yang sering di temukan di leher bagian lateral adalah cystic hygromas. ${ }^{21}$ Pada leher bagian tengah, kista duktus tiroglosus dan kista timus paling sering ditemukan. ${ }^{21}$ Diagnosis banding lain meliputi kista epidermoid, kista dermoid, ranula, sialolithiasis ${ }^{6}$, schwannoma, lipoma, fibroma, hemangioma, keganasan, dan kista teratoma $^{13}$

\section{Terapi dan Prognosis}

Terapi definitif untuk kasus kista teratoid adalah dengan eksisi kista secara komplit (cystectomy). ${ }^{2,6}$ Jika kista teratoid dapat terdiagnosis lebih awal dan dilakukan eksisi secara komplit maka prognosis baik Kekambuhan terjadi bila eksisi kista tidak komplit. Komplikasi pasca operasi jarang terjadi. Kira-kira 5\% kista dermoid dilaporkan mengalami perubahan menjadi keganasan, ${ }^{22}$ tetapi hanya variasi kista teratoid yang dapat mengalami perubahan keganasan tersebut. ${ }^{16}$

\section{KASUS}

Seorang pasien laki-laki berumur 49 tahun datang ke poliklinik Telinga Hidung Tenggorok Bedah Kepala dan Leher (THT-KL) RSUP. Dr. M. Djamil Padang dengan keluhan benjolan di leher bagian depan yang terasa makin membesar sejak dua minggu sebelum masuk rumah sakit. Benjolan dirasakan sudah sejak satu tahun yang lalu. Benjolan tidak terasa nyeri, tidak pernah timbul warna merah pada benjolan. Tidak terdapat gangguan menelan, suara serak dan sesak nafas. Tidak disertai dengan keluhan keringat yang berlebihan, dada rasa berdebar-debar, mata menonjol, gemetaran dan tidak terdapat penurunan berat badan yang drastis. Tidak ada riwayat penyinaran di daerah leher. Tidak ada riwayat trauma pada leher. Tidak ada anggota keluarga lain yang sakit seperti ini dan tidak ada riwayat keganasan di keluarga. Pemeriksaan kedua telinga didapatkan dalam batas normal. Pemeriksaan hidung rinoskopi anterior dan posterior dalam batas normal. Pemeriksaan tenggorok dalam batas normal. Pada pemeriksaan fisik regio colli anterior dengan

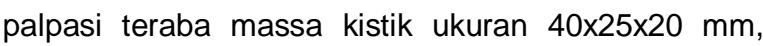
kenyal padat, berbatas tegas, permukaan rata, tidak ada nyeri tekan, dan benjolan ini ikut bergerak waktu pasien menelan dan ketika lidah dijulurkan. Tidak ditemukan pembesaran kelenjar getah bening. Pasien didiagnosis dengan suspect kista duktus tiroglosus didiagnosis banding dengan kista dermoid (Gambar 2)
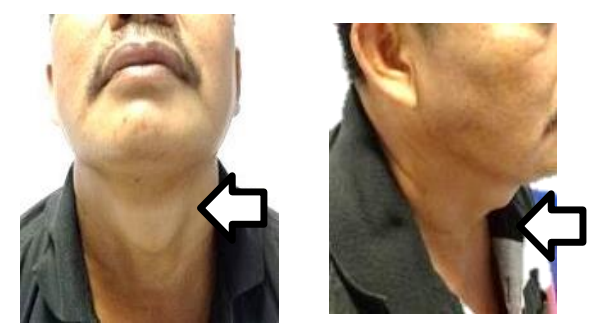

Gambar 2. Foto pasien sebelum operasi

Pada pasien ini dilakukan tindakan pemeriksaan laboratorium didapatkan $\mathrm{Hb} \quad 14,9 \mathrm{~d} / \mathrm{dll}$, leukosit

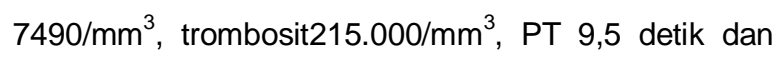
APTT 28,5 detik, GDS 96 mg/dl, SGOT 27 u/l, SGPT $37 \mathrm{u} / \mathrm{l}$, ureum $19 \mathrm{mg} / \mathrm{dl}$, kreatinin 1,1 mg/dl. Pada pemeriksaan CT Scan tiroid dan leher potongan aksial, koronal dan sagital irisan $3 \mathrm{~mm}$ tanpa kontras: tampak lesi hipodens di regio colli anterior, pada linea mediana, bentuk membulat, batas tegas, tepi regular bersepta, ukuran $4 \times 3,5 \times 3,4 \mathrm{~cm}$. Tiroid dekstra dan sinistra: bentuk, ukuran, densitas normal. Laring tampak simetris, tak tampak massa. Trakea simetris, tidak menyempit. Tulang intak, tak tampak destruksi. Tidak tampak pembesaran kelenjar getah bening regional. Kesan suspect Thyroglossal Duct cyst, diagnosis banding Dermoid cyst. (Gambar 3). Pasien dipersiapkan untuk operasi eksisi kista duktus tiroglosus dengan prosedur Sistrunk dalam anestesi umum.

Pada pasien dilakukan operasi eksisi kista. Pasien tidur di meja operasi posisi supine dan leher hiperekstensi dalam narkose umum, dilakukan tindakan aseptik dan antiseptik, dibuat insisi secara horizontal mengikuti garis kulit tepat diatas kista, insisi diperdalam sampai terlihat otot platisma dan menembusnya, dibuat flap keatas sampai submental dan flap ke bawah sampai $20 \mathrm{~mm}$ di kaudal tepi bawah kista. Dibuat insisi secara vertikal pada fasia servikal, terlihat otot strap muscle yaitu sternohyoid, dipisahkan di garis tengah ke kanan dan ke kiri secara tumpul sehingga dapat dievaluasi dinding kista. Terlihat massa kista berlobus-lobus yang mendorong 
membrana tirohyoid ke posterior. Kista dilepaskan secara tumpul dari membrana tirohyoid. Dilakukan evaluasi kista, tidak tampak duktus yang menuju ke bawah tulang hyoid. Kista dieksisi secara komplit. Perdarahan dirawat, dilakukan tes Bubble tidak didapatkan gelembung udara, drain dipasang, luka dijahit lapis demi lapis, otot dan fasia muskulus sternohyoid dijahit dengan chromic 3.0, dilanjutkan dengan jahitan subkutikuler dengan prolene 5.0, dan operasi selesai. Kista yang dieksisi berukuran $35 \times 25 \times 15$ mm (Gambar 4).
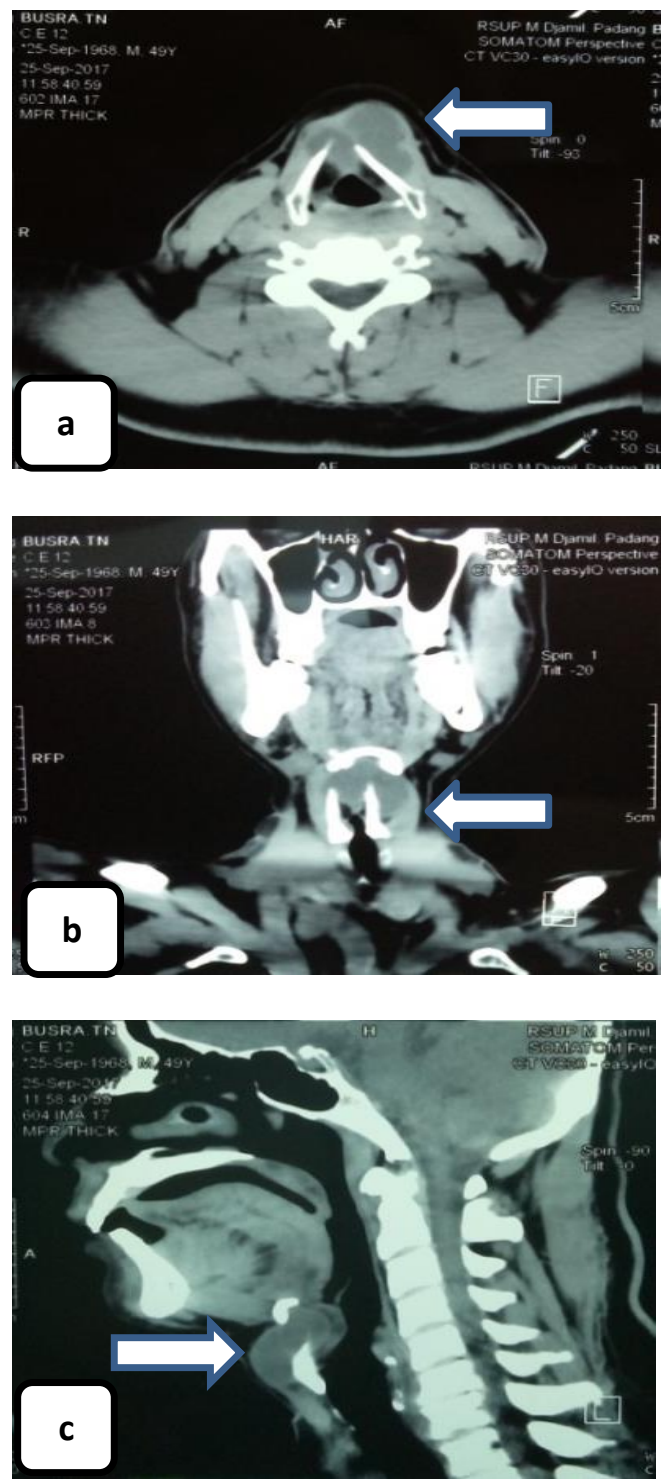

Gambar.3. CT scan tiroid dan leher : a. Potongan aksial, b. Potongan koronal, c. Potongan sagital, yang memperlihatkan tampak lesi hipodens di linea mediana leher (tanda panah)

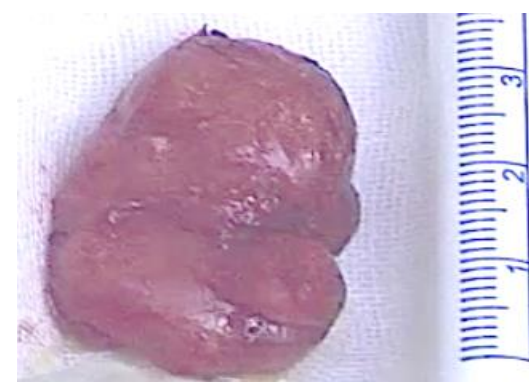

Gambar 4. Kista yang dieksisi, warna merah

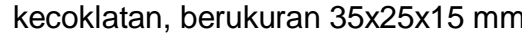

Follow up hari pertama, tidak ada demam, suara serak, sesak nafas dan gangguan menelan. Terdapat nyeri minimal pada regio operasi. Pada regio colli anterior, luka operasi tertutup perban, darah merembes tidak ada, drain \pm 20 cc. Terapi injeksi Seftriakson 2x1 gram (IV), drip tramadol $50 \mathrm{mg} / \mathrm{kolf}$ dalam $500 \mathrm{ml} \mathrm{RL} 8$ jam/kolf, injeksi Deksametason 3x5mg (IV) dan injeksi Asam traneksamat 3x500mg (IV) dilanjutkan.

Follow up hari kedua, pasien tidak ada keluhan. Drain dibuka dan pada regio colli anterior didapatkan luka operasi tenang tidak terdapat tanda infeksi. Terapi injeksi Seftriakson 2x1 gram (IV) dilanjutkan. Follow up hari ketiga, pasien tidak ada keluhan. Pasien diperbolehkan pulang, diberikan terapi oral Sefiksim 2x200 mg dan lbuprofen 3x400mg.

Kontrol hari ketujuh pasca operasi, keluhan tidak ada, jahitan operasi dilepas. Terapi oral dilanjutkan. Kontrol minggu kedua pasca operasi, pasien tidak ada keluhan, luka operasi baik. Hasil pemeriksaan patologi anatomi: tampak potongan jaringan dengan stroma jaringan ikat mengandung rongga yang dilapisi epitel respiratorius, lumen berisi sekret, pada stroma jaringan ikat diantaranya tampak bagian perdarahan dan kapiler hiperemis serta adanya folikel tiroid dan terdapat pula rongga dilapisi epitel berlapis gepeng. dengan kesan adalah suatu kista teratoid (Gambar 5)

Kontrol satu bulan setelah operasi, keluhan tidak ada, luka bekas operasi baik, hiperemis tidak ada, edema tidak ada (Gambar 6). 

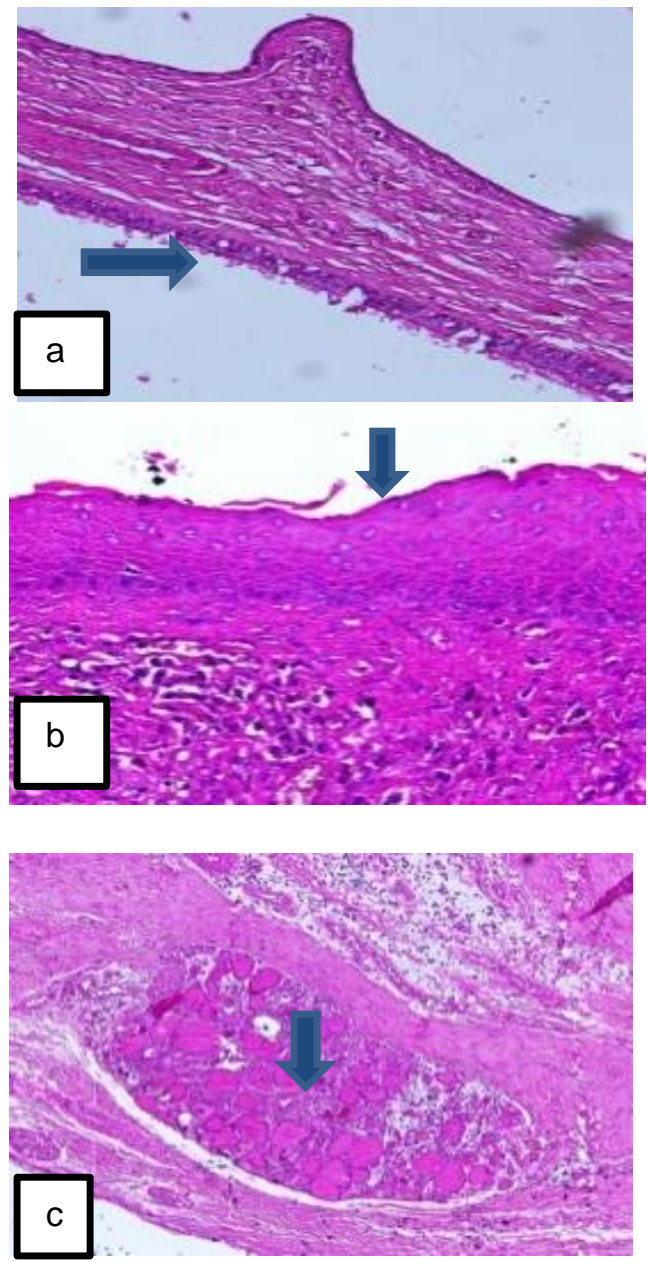

Gambar 5. a).Tampak gambaran salah satu dinding kista yang dilapisi epitel respiratorius (tanda panah). b). Tampak gambaran salah satu dinding kista yang dilapisi epitel berlapis gepeng (tanda panah), c). Tampak gambaran folikel tiroid (tanda panah)

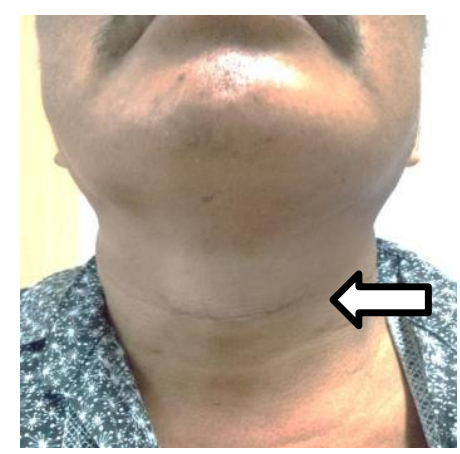

Gambar 6. Foto pasien kontrol satu bulan setelah operasi

\section{PEMBAHASAN}

Kista teratoid adalah variasi jarang dari kista dermoid. Kista teratoid timbul dari diferensiasi ektodermal sel multipotential sepanjang proses fusi embrionik. Faerber seperti yang dikutip Liang et al (2012) melaporkan hanya sebanyak 7\% dari kista dermoid terdapat di kepala-leher Kejadian kista teratoid. $^{23}$ Menurut Nagar dan Baratz (1993) hanya sekitar $1,8 \%$ dari semua jenis kista dermoid. ${ }^{4}$

Palaskar et al (2014) mengemukakan insiden kista teratoid di kepala-leher lebih banyak di temukan pada laki-laki usia dedade kedua dan ketiga. ${ }^{2}$ Longo seperti dikutip oleh Shylaja et al (2011) menemukan kejadian kista lebih banyak pada laki-laki daripada wanita dengan rasio 3:1 dengan rata-rata pada usia 28 tahun. Shylaja et al menyatakan bahwa pertumbuhan kista juga di pengaruhi oleh stimulus hormonal selama puberitas dan hipersekresi kelenjar sebasea, sehingga angka kejadian sering meningkat pada dewasa muda (usia 16-40 tahun). ${ }^{1}$ Pada pasien ini gejala baru dirasakan pada usia 49 tahun.

Kista teratoid secara klinis menurut Alsharif dan Zhao (2009) merupakan suatu massa kistik yang asimptomatik, tidak nyeri dan pertumbuhannya sangat lambat, tetapi berpotensi untuk menjadi sangat besar. ${ }^{6}$ dan menurut Menditti seperti yang dikutip oleh Palaskar et al, kista yang berukuran sangat besar dapat menimbulkan gejala obstruksi dengan disfagia, disfonia dan dispnu. ${ }^{2}$ Pada kasus ini, pasien datang dengan keluhan benjolan di leher depan yang semakin besar sejak 2 minggu sebelum masuk rumah sakit. Benjolan sudah dirasakan pasien sejak 1 tahun yang Ialu. Benjolan tidak nyeri dan tidak merah.

Etiologi kista dermoid belum diketahui secara pasti. Kista dermoid dapat bersifat kongenital atau didapat, walaupun secara klinis dan histopatologis tidak terdapat perbedaan diantara keduanya. Gol et al (2005) mengemukakan terdapat teori yang menyatakan bahwa kista dermoid kongenital merupakan lesi disembryogenic yang berasal dari elemen ektoderm yang terjebak pada saat penggabungan antara lengkung brankialis pertama dan kedua yang terjadi pada masa gestasi 3 sampai 4 
minggu. ${ }^{13}$ Kista dermoid didapat menurut Anantanarayan et al (2010), terjadi akibat trauma yang menyebabkan implantasi sel epitel ke jaringan yang lebih dalam saat terjadi trauma, atau karena oklusi duktus kelenjar sebasea. ${ }^{24}$

Penegakan diagnosis kista teratoid merupakan hal yang cukup sulit dan biasanya diagnosis pasti ditegakkan setelah operasi. Selain pemeriksaan fisik yang lengkap, juga diperlukan pemeriksaan penunjang yaitu pemeriksaan histopatologis dan radiologi seperti ultrasonografi (USG), CT Scan dan MRI. Pemeriksaan radiologis bertujuan untuk mengetahui lokasi, ukuran dan perluasan kista, serta hubungan kista dengan struktur sekitarnya, sehingga memudahkan operator untuk memilih pendekatan operasi yang tepat. Menurut Mittal et al (2012), CT Scan merupakan pemeriksaan radiologi yang paling superior dalam menentukan perluasan kista dan bermanfaat dalam memberikan gambaran kalsifikasi dan lemak dalam lesi. ${ }^{17}$ Pada kasus ini pemeriksan penunjang yang digunakan adalah CT Scan, diagnosis kista teratoid pada kasus ini ditegakkan berdasarkan pemeriksaan histopatologis setelah dilakukan eksisi kista secara komplit. Pada pasien ini dilakukan pemeriksaan CT Scan tiroid dan leher tampak lesi hipodens di regio colli anterior, pada linea mediana, bentuk membulat, batas tegas, tepi regular bersepta, ukuran $4 \times 3,5 \times 3,4 \mathrm{~cm}$.

Meyer seperti yang dikutip oleh Nagar dan Baratz mengemukakan konsep bahwa secara histologis terdapat 3 varian kista dermoid yaitu kista epidermoid, kista dermoid sejati dan teratoid. Pada jenis epidermoid, kista dilapisi oleh epitel gepeng tanpa disertai adneksa. Sedangkan pada kista dermoid, selain dilapisi oleh epitel gepeng, juga disertai adneksa seperti rambut, folikel rambut dan kelenjar sebasea. Pada teratoid, selain epitel berlapis gepeng dan adneksa, juga ditemukan adanya elemen mesoderm seperti otot, tulang, dan kartilago dan elemen entoderm seperti epitel respiratorius, kelenjar eksokrin (bronkial, gastric, intestinal) dan organ solid (pankreas, liver, ginjal, paru, tiroid). ${ }^{4}$

Bonilla et almengungkapkan kista teratoid variasi yang paling jarang ditemukan dibandingkan kista epidermoid dan dermoid sejati. ${ }^{5}$ Pada kasus ini, secara histopatologi merupakan kista teratoid karena kista dilapisi oleh epitel respiratorius dan terdapat rongga yang dilapisi oleh epitel gepeng dan ditemukan adanya folikel tiroid.

Diagnosis banding kista teratoid sangat luas, dan banyak ahli menyatakan bahwa diagnosis akhir hanya bisa didapatkan dari pemeriksaan histopatologis dari spesimen hasil operasi. Diagnosis banding untuk kista teratoid menurut New dan Erich seperti yang dikutip oleh Liang et al (2012) antara lain kista epidermoid, kista dermoid, kelenjar tiroid ektopik, kista duktus tiroglosus, hemangioma/ limfangioma, sialadenitis atau kista teratoma. ${ }^{23}$ Dutta et al (2013) juga mengemukakan diagnosis banding lain seperti kista higroma, kista celah brankialis, mucocele dan ranula. ${ }^{3}$ Pada kasus ini didiagnosis banding dengan kista duktus tiroglosus, tetapi intraoperatif ditemukan kista berwarna merah kecoklatan dan berisi cairan kekuningan dan mengkilat dan tidak ditemukan adanya duktus yang menghubungkan kista dengan bagian tengah tulang hyoid.

Terapi definitif untuk kasus kista teratoid menurut Alsharif dan Zhao (2009) adalah dengan eksisi kista (cystectomy) secara komplit. ${ }^{6}$ Terdapat dua pendekatan operasi yaitu pendekatan intraoral dan ekstraoral (insisi leher) atau kombinasi keduanya, tergantung ukuran dan lokasi kista teratoid. Eksisi kista pada kasus ini dilakukan dengan melakukan insisi transversal sesuai garis kulit di atas kista, sehingga memudahkan visualisasi kista dan kontrol terhadap struktur sekitarnya.

Prognosis kista teratoid setelah dilakukan eksisi secara komplit sangat baik dan sangat jarang mengalami rekurensi. Tsirevelou et al (2009) mengemukakan beberapa penulis melaporkan sekitar $5 \%$ dari kista dermoid mengalami perubahan ke keganasan. $^{22}$ Kandogan et al menyebutkan hanya tipe teratoid dapat berubah menjadi ganas. ${ }^{16}$

\section{SIMPULAN}

Diagnosis kista teratoid tidak dapat ditegakkan tanpa adanya anamnesis yang baik dan pemeriksaan penunjang yang seperti USG, CT Scan, MRI dan konfirmasi dari patologi anatomi. 
Penatalaksanaan definitif untuk kista teratoid adalah dengan eksisi kista, jika kista ini dieksisi dengan sempurna, maka angka kekambuhannya sangat jarang. Kista teratoid dapat mengalami perubahan menjadi ganas, untuk itu diperlukan follow up periodik pasca operasi.

\section{DAFTAR PUSTAKA}

1. Shylaja M, Attur K, Mohtta A, Goud S. Teratoid cyst of tongue: report of a rare variant of dermoid cyst and review of literature on dermoid cyst. Indian Journal of Stomatology. 2011;2(4).

2. Palaskar SJ, Garde J, Bartake A, Narang B. Teratoid cyst of the oral cavity: a rare entity. Journal of oral and maxillofacial pathology: (JOMFP). 2014;18(3):469.

3. Dutta M, Saha J, Biswas G, Chattopadhyay S, Sen I, Sinha R. Epidermoid cysts in head and neck: our experiences, with review of literature. Indian Journal of Otolaryngology and Head \& Neck Surgery. 2013;65(1):14-21.

4. Nagar H, Baratz M. Congenital sublingual teratoid cyst. Case report. International journal of oral and maxillofacial surgery. 1993;22(1):44-5.

5. Bonilla JA, Szeremeta W, Yellon RF, Nazif M. Teratoid cyst of the floor of the mouth. International Journal of Pediatric Otorhinolaryngology. 1996;38(1):71-5.

6. Alsharif MJ, Zhao Y. Teratoid cyst of floor of the mouth: a clinicopathologic study of 20 Chinese patients. International Journal of Surgical Pathology. 2009;17(2):111-5.

7. Ranabhat S, Tiwari M, Maharjan S. Teratoid cyst of the postauricular region: the first ever case report. Case Reports in Pathology. 2017.

8. Steven T, Wright M, Francis B. Quinn J, Matthew W. Ryan M. Embryology of the neck and neck masses. Grand Rounds Presentation, UTMB, Dept of Otolaryngology. 2005 (diakses 2019). Tersedia dari: https://dentisty.org/title-embryology-of-theneck-and-neck-masses-source-grand-roun.html

9. Sadler TW. Langman's medical embryologi. Edisi ke-12. Philadelphia: Lippincott Williams \& Wilkins, a Wolters Kluwer business; 2012.hlm.260-86.
10. Gaddikeri S, Vattoth S, Gaddikeri RS, Stuart R, Harrison $\mathrm{K}$, Young $\mathrm{D}$, et al. Congenital cystic neck masses: embryology and imaging appearances, with clinicopathological correlation. Current problems in diagnostic radiology. 2014;43(2):5567.

11. Acierno SP, Waldhausen JH. Congenital cervical cysts, sinuses and fistulae. Otolaryngologic Clinics of North America. 2007;40(1):161-76.

12. Yellon RF. Congenital cyst and sinuses of the head and neck. Dalam: Johnson JT, Rosen CA, editor. Bailey's head and neck surgery: Otolaryngology. Edisi ke-5. USA: Lippincott Williams \& Wilkins; 2013.hlm.1607-16.

.13.Göl IH, Kiyici H, Yildirim E, Arda IS, Hiçsönmez A. Congenital sublingual teratoid cyst: a case report and literature review. Journal of Pediatric Surgery. 2005;40(5):e9-e12.

14. Burger MF, Holland P, Napier B. Submental midline dermoid cyst in a 25-year-old man. Ear Nose Throat J. 2006;85(11).

15. Elias LSA, Oton-Leite AF, Silva CM, Ribeiro-Rotta RF, Batista AC, Mendonça EFd. Epidermoid cyst: highlights on diagnosis and magnetic resonance imaging features. Revista Odonto Ciência. 2010; 25(2):204-7.

16. Kandogan T, Koç M, Vardar E, Selek E, Sezgin Ö. Sublingual epidermoid cyst: a case report. Journal of Medical Case Reports. 2007;1(1):87.

17. Mittal MK, Malik A, Sureka B, Thukral BB. Cystic masses of neck: A pictorial review. The Indian Journal of Radiology \& Imaging. 2012;22(4):334.

18. Haynes J, Arnold KR, Aguirre-Oskins C, Chandra $\mathrm{S}$. Evaluation of neck masses in adults. American Family Physician. 2015;91(10).

19. Sanal HT. Ultrasound finding of dermoid cysts located in neck region: sack-of-marbles sign. KBB Forum, Electronic Journal of Otolaryngology-Head and Neck Surgery. 2008;7(1).

20. Smirniotopoulos JG, Chiechi MV. Teratomas, dermoids, and epidermoids of the head and neck. Radiographics. 1995;15(6):1437-55.

21. Schwetschenau E, Kelley DJ. The adult neck mass. American Family Physician. 2002; 66 (5): 831-8. 
22. Tsirevelou P, Papamanthos M, Chlopsidis $P$, Zourou I, Skoulakis C. Epidermoid cyst of the floor of the mouth: two case reports. Cases journal. 2009;2(1):9360.

23. Liang $Y$, Yang $Y$, Zhang $Y$. Retrospective analysis of ten cases of congenital sublingual teratoid cyst. European journal of paediatric dentistry: official journal of European Academy of Paediatric Dentistry. 2012;13(4):333-6.
24. Anantanarayanan P, Manikandhan R, Bhargava D, Sivapathasundaram B. Sub-lingual epidermoid cyst. Head and Neck Pathology. 2010;4(2):136-8.

25.Zhu H, Gong B, Han C, Li Z, Farman AG, Scarfe WC. The utility of fistulography in the diagnosis of thyroglossal duct cyst with fistulous tract: Case report and literature review. Radiology Case Report. 2015;10(2). 